\title{
Special Issue on Indeterminacies and mismatches in grammatical systems
}

https://doi.org/10.1515/zfs-2020-2022

This issue is the first special issue of Zeitschrift für Sprachwissenschaft to be published exclusively online, as a third issue complementing this year's two regular issues. ZS online-only issues are meant to offer a forum for one of the AGs (workshops) that are part of the annual conference of the Deutsche Gesellschaft für Sprachwissenschaft (DGfS, the Linguistic Society of Germany) to publish selected contributions of their AG. The present issue has emerged from the Workshop Contrast and Opposition in 'Free' Phenomena, organized by the guest editors Volker Struckmeier and Andreas Pankau and held at the 41st Annual Conference in Bremen, in March 2019.

Sabine Arndt-Lappe, Stefanie Dipper, Gerhard Jäger,

Dejan Matić, and Natascha Pomino Editorial staff of the Zeitschrift für Sprachwissenschaft 